\title{
CORRECTION
}

\section{Correction to: KS(conf): A Light-Weight Test if a Multiclass Classifier Operates Outside of Its Specifications}

\author{
Rémy Sun ${ }^{1}$. Christoph H. Lampert ${ }^{2}$
}

Received: 23 October 2019 / Accepted: 29 October 2019 / Published online: 9 November 2019

(c) The Author(s) 2020

\section{Correction to: \\ International Journal of Computer Vision https://doi.org/10.1007/s11263-019-01232-x}

The original version of this article contained a mistake in the denominator of Eq. (1). The correct expression is

$F(p)=\frac{k}{n+1}+\frac{p-Z_{k}^{\mathrm{val}}}{(n+1)\left(Z_{k+1}^{\mathrm{val}}-Z_{k}^{\mathrm{val}}\right)}$

The original article has been corrected.

Open Access This article is licensed under a Creative Commons Attribution 4.0 International License, which permits use, sharing, adaptation, distribution and reproduction in any medium or format, as long as you give appropriate credit to the original author(s) and the source, provide a link to the Creative Commons licence, and indicate if changes were made. The images or other third party material in this article are included in the article's Creative Commons licence, unless indicated otherwise in a credit line to the material. If material is not included in the article's Creative Commons licence and your intended use is not permitted by statutory regulation or exceeds the permitted use, you will need to obtain permission directly from the copyright holder. To view a copy of this licence, visit http://creativecomm ons.org/licenses/by/4.0/.

Publisher's Note Springer Nature remains neutral with regard to jurisdictional claims in published maps and institutional affiliations.

The original article can be found online at https://doi.org/10.1007/ s11263-019-01232-x.

Christoph H. Lampert

chl@ist.ac.at

Rémy Sun

remy.sun@ens-rennes.fr

1 ENS Rennes, Bruz, France

2 IST Austria, Klosterneuburg, Austria 